\title{
Legal Basis of Protection of Nature and the Role of Courts while Protecting Nature in Lithuania
}

\section{凡目 Gintautas Danishauskas}

Associate Professor, Department of Criminal Law, Mykolas Romeris University. Address: 20 Ateities Str., LT-08303 Vilnius, Lithuania. E-mail: danigint@mruni.eu_

\section{国国 Abstract}

It is commonly understood that nature has the biggest value for humanity. The article examines and analyzes the legal framework for nature conservation and issues related to state institutions including the judiciary's role in protecting and preserving the environment and its individual objects. Also article analysis how courts contribute to the highest human values - the protection and enhancement of nature while administering justice. On nature and its resources depends what kind of economy we will have and develop in the future on state and global scale. While speaking about the economic issues O. Blanchard states that it is also important for everyone to know not only what to expect today, but what to expect in the future too. Since the nature and its objects are especially important human value for their protection the state institutions, inspections and judicial authority are mobilized as The Constitution of the Republic of Lithuania states that judicial authority works to protect the human rights. It means that the judicial power as well as other two powers is also responsible for nature protection as it is a right of all humans. The work also analyzes the statistics of nature protection and the executive's contribution to the protection of nature. The topic is relevant because it examines the issue concerning not only a particular area of our social life, but also each one of us. In international and national acts of nature protection and in final decisions of courts reinforces the legal imperative of providing a regulatory framework for the protection of nature and also establishes the right for all subjects to use natural goods. This inevitably affects not only each one of us but also the whole society and the state. Although the topic of environmental protection is not basically new, there is no detailed examination about current legal framework and judicial significance for the protection of nature in Lithuanian researches. That is why this issue is not fully investigated and it can manifest only by the individual phrases without a specific study conclusions.

\section{0-1国 Keywords}

nature; protection; natural objects; convention; Lithuania; public interest; Constitution; court decisions; statistics.

For citation: Danishauskas G. (2019) Legal Basis of Protection of Nature and the Role of Courts while Protecting Nature in Lithuania. Pravo. Zhurnal Vysshey shkoly ekonomiki, no 4, pp. 208-221 (in English) 


\section{Introduction}

The aim of study is to determine whether the legal basis for nature protection in Lithuania is enough, what monetary costs can be allocated to the protection and what is the role of the judiciary in protecting and preserving the natural values. Research tasks are to analyze international and national legal acts on environmental protection, to access statistics relating to nature protection issues, to analyze the role of the courts in the process. Tested hypotheses is whereas at the level of international and national Constitutional law natural values are associated with basic human rights it is assured by public authorities, including the judicial justice. Research methods include: analysis, comparison, logical, statistical analysis. Research objective is to analyze issues related to the legal framework development of nature protection of Lithuania as well as giving and operational basis for the courts and their role in preserving and protecting the environment and its individual objects.

\section{International and national law in Lithuanian environmental activities and nature conservation priorities in government economic policy}

Almost half a century ago - in 1972 in the United Nations Declaration of the Stockholm Conference were raised questions related to a healthy environment and they were associated with the human right to life. It was the first large-scale conference of United Nations held to discuss international environmental issues. It was attended by 113 countries and over 400 international and non-governmental organizations. Even now the Conference is recognized as one of the main events regarding the start of the contemporary international environmental policy field [Baylis J., Smith S., 2005: 454-455]. However, in spite of international documents and legal acts adopted in Lithuania in the field of nature protection, nature is still being damaged, polluted and its protection is inadequate. In The United Nations Stockholm Conference in 1972 (United Nations Conference on the Human Environment) dedicated to discussion of the environmental issues, the declaration was adopted which highlights that both natural and human built environment is mandatory for human well-being and fundamental human rights, to guarantee the right to life itself. The first principle of the Declaration stated that person has the fundamental right to freedom, equality and adequate conditions of life in the environment with such quality that allows to live in dignity and ensures well-being of human. And human has a duty to protect and improve the environment for present and future generations ${ }^{1}$. Ten years after a conference in

${ }^{1}$ Declaration of the United Nations Conference on the Human Environment. Available at: http:// www.unep.org/Documents.Multilingual/Default.asp?DocumentID=97\&ArticleID=1503\&l=en $>$ (access ed: 20.03.2017). 
Nairobi was held dedicated to discussion of the results of environmental protection, conference is also known as Stockholm+10. It was attended by 134 states. The Conference admitted that the objectives regarding the protection of the nature from past Stockholm declaration were not fulfilled and in 10 years we can notice the environmental deterioration. In the adopted Declaration of Nairobi was reannounced the support for the Stockholm Declaration and expressed desire to strengthen the environmental protection program [De Sombre E., 2006: 24-25]. In the 1990's the European Council also announced that the European Community and its Member States must have to take steps to guarantee the human rights to a clean and healthy environment including air quality, rivers, lakes, coasts and sea waters, quality of food and drinking water, protection from noise, protection from the pollution, protection of flora and fauna, protection for the landscape and other natural heritage, the quality and enjoyment of residential areas [Kramer L., 2012: 2].

That is why in the Constitution of the Republic of Lithuania, adopted in 1992, while consolidating the fundamental human rights such as the right to life, health, freedom, property the right to nature values was consolidated too. But it is important to remember that with this right exists aligned with responsibility - we must have to protect the nature ${ }^{2}$. This indicates that this value as much as any other value established in the Constitution has a large meaning in the society. The article Nr. 53 of the Basic Law enshrined the provision that the state and each person must have to protect the environment from harmful effects. The article 54 of the Constitution prescribes that the state has a duty to take care of the natural environment, wildlife and plants, individual objects and the areas of particular value, to ensure the sustainable use as well as their restoration and augmentation of natural resources. It is emphasized that the law prohibited the destruction of land and its underground, the pollution of water and air, radioactive impact on the environment as well as depletion of wildlife and plants. While emphasizing the importance of natural objects and solving the property issues, the article 47 of the Constitution is enshrined that the Republic of Lithuania exclusively owns: subsurface resources, as well as nationally significant internal waters, forests, parks, roads, historical, archaeological and cultural objects. The Republic of Lithuania also has exclusive rights to the airspace over its territory, its continental shelf and economic zone in the Baltic Sea. In the Republic of Lithuania the foreign entities can acquire ownership of lands, internal waters and forests only by a constitutional law. The land ownership according to conditions of law can belong to a foreign state - to set up its diplomatic and consular offices ${ }^{3}$.

\footnotetext{
${ }^{2}$ Lietuvos Respublikos Konstitucija. Valstybès žinios. 1992, Nr. 33-1014.

${ }^{3}$ Lietuvos Respublikos Konstitucija. Valstybès žinios. 1992, Nr.33-1014.
} 
It means that the Basic Law obligates the state institutions and first of all the parliament to create the legal framework to protect and defend the natural values, and executive power to allocate the necessary material resources. However, what the significance the protection of nature has among the other priority spending of Government, we can see in statistics: from yearly government spending allocated to the gross national product (GNP) — Gross Domestic Product GDP - 34,4\%-34,8\%, an average for nature protection is only $0,6 \%$, while for the defense $-1,1 \%$, for the public order $-1,7 \%$, for the economy $-3,2 \%$, for health care $-5,5 \%$, and for social security $-11,5 \%$ GNP. Although statistics may slightly change, the change wouldn't be significant. For example, if in 2004 for these costs were allocated $34,8 \%$ at 2019 it will be 34,4 of GNP 4 . Such funds for nature conservation, compared with other fields, cannot be sufficient. The larger funds allocated to other purposes increases the human economic activities by itself and it inevitably leads to increased environmental pollution and requires more funds to its reconstruction. Profit seeking and non-profit economic entities who are polluting the environment are not always interested and capable to restore the damaged environment without additional obligations. That is why the comparative GDP funds has to be allocated regarding the economic activity scale, which is directly dependent on the size of GDP funding for their activities. Overall the economic activities have the greatest impact for the natural contamination and it is even associated with climate change.

Intergovernmental Panel on Climate Changes in its fourth assessment report and in other published scientific studies indicate that the economic activities which pollutes the nature has the greatest influence on the climate system [Satkūnas J., 2014: 15]. That is why the most serious environmental problems remains in the most densely populated cities in Lithuania and especially in the capital - Vilnius, where the economic activities are developed the most. Over the past few years the content of oil and other pollutants grew by $18,4 \%$ in region of Vilnius [Mareškevičienè I., 2015: 65]. Due to the problem of under-proportional funding for nature conservation and government policy, in this field the judicial activities in the protection and restoration of natural objects acquired a great importance. Aarhus Convention is an international document that also became a component of national system and it provides a legal framework for all interested parties to apply to the court regarding the nature protection issues ${ }^{5}$. Convention on access to information, public participation in decision-making and access to justice in environmental matters" was also ratified by the Parliament of the Re-

${ }^{4}$ Available at: http://ec.europa.eu/europe2020/pdf/csr2016/sp2016_lithuania_lt.pdf (accessed: 7.04.2017).

${ }^{5}$ Convention on access to information, public participation in decision-making and access to justice in environmental matters. Available at: http://www.unece.org/fileadmin/DAM/env/pp/documents/ cep43e.pdf [accessed: 21.03.2017]. 
public of Lithuania in 2001 and it became a part of national law system ${ }^{6}$. The main goal of Convention is to protect human rights of current and future generations on healthy and friendly environment, to ensure the right to information, the right to participate in decision-making process and the right to apply to the court about environmental protection issues. The Convention highlights the main focus of nature conservation: 1) it links the right on healthy environment with human rights; 2) highlights our duties for the future generations; 3 ) it emphasizes that the sustainable development of nature protection is only possible if all concerned groups are involved; 4) links the accountability of authorities and the protection of environment; 5) puts efforts to mobilize the communication of the public and government authorities democratically. According to Convention anyone can apply to court regarding nature protection questions. The concerned parties may be: 1 . The society means one or more individual or legal persons, and in accordance with national legislation or practice their associations, organizations or groups. 2.,,The concerned society" means the society, affected or likely to influence environmental decisions or having an interest in the decision-making process. According to non-governmental organizations promoting environmental protection and in accordance with national law are deemed to have an interest.

\section{The role of the courts in protecting and restoring the damaged natural objects}

Taking into account the particular importance of nature preservation, the highest Lithuanian court engaged in constitutional review - The Constitutional Court of the Republic of Lithuania gives the imperatives for all other courts and notes that one of the state performance targets expressis verbis enshrined in the Constitution is to ensure people's rights to a healthy and a clean environment. It established the constitutional imperative of environmental protection. It is emphasized that a person's right to a healthy environment is required for a dignified life and access to many other constitutional rights ${ }^{7}$. Mirroring this court decision, The Supreme Administrative Court of the Republic of Lithuania repeats the same provision in cases. No. A520-211 / 2013 and No. A602-186/2013. In these cases the courts also associate the healthy nature with basic constitutional human rights. On the content of law the new law can only arise from the executing law. That is why the large industrial companies, who are the most polluting entities, are obligated

\footnotetext{
${ }^{6}$ Konvencija "Dèl teisès gauti informaciją, visuomenès dalyvavimo priimant sprendimus ir teisès kreiptis į teismus aplinkos klausimais”. Valstybès žinios. 2001, Nr.73-2565.

7 Konstitucinio Teismo 1998 m. birželio 1 d., 2003 m. spalio 29 d., 2005 m. gegužès 13 d., 2006 m. kovo 14 d., 2007 m. liepos 5 d., 2009 m. rugsèjo 2 d., 2011 m. sausio 31 d. nutarimai.
}

8 Vyriausiojo administracinio teismo biuletenis. 2013, Nr. 26, p. 271-301;2013, Nr. A602-186/2013. 
to pay the funds to the restoration of nature. That is why the corporate investment in environmental protection in 2015 was 88 million EUR and it distributed by the major nature object for human rights: for protection of water resources $-66 \%$, for waste collection and processing $-17,1 \%$, for air protection $-14,7 \%$, for other environmental protection activities $-2,2 \%$. However, it is clear that corporate investment in environmental protection from 2011 decreased by 5,9\% ${ }^{9}$. It should be noted that the most polluting entities - refined petroleum products and food manufacturers for the protection of nature gives about $56,4 \%$ from the companies funding [Jablonskienè A., 2014: 44]. Industrial companies together becomes a primary polluters. The Constitutional Court of the Republic of Lithuania obligated such entities to pay for natural pollution. In court jurisprudence the principled provision is established as "the polluter pays" the costs of waste management. It means that the costs of waste management has to be paid by the primary waste producer or by the current or previous waste holders and the manufacturer or importer of the products which produce waste which pollutes the environment ${ }^{10}$. However, if the companies or other entities are not following the rules provided by the Environmental Protection Law of the Republic of Lithuania, article 7 also provides a right to concerned individuals to apply to a court by implementation of right to receive information about the environment. It also provides a right to concerned society to apply to court according to the law for the protection of public interest and protection of the environment and natural resources ${ }^{11}$. Apart from the Aarhus Convention and the specific Environmental Protection Law of the Republic of Lithuania that regulates environmental legal relations the right to go to court for concerned parties also gives the Law of the Administrative Proceedings of the Republic of Lithuania ${ }^{12}$. The article No. 5 of this Law regulates that the court shall hear the case by the person or his representative who applies for the protection of the right or legitimate interest by the complaint or request.

Furthermore, the article 56 complements and specifies the subjects who can apply to the court regarding mentioned matters. It is stated that the prosecutor in cases prescribed by law, administrative bodies, public authorities, organizations, departments and individuals can apply to the court with a petition to protect the

9 İmonių išlaidos gamtos apsaugai. Verslo žinios. Available at: http://vz.lt/archive/article/2013/11/12/ imoniu-islaidos-aplinkos-apsaugai-sumazejo-5-9\#ixzz4dSfi2vto[accessed: 07.04.2017].

${ }^{10}$ Lietuvos Respublikos Konstitucinio Teismo 2014 m. gegužès 9 d. Nutarimas „Dèl Lietuvos Respublikos Vyriausybès 2002 m. balandžio 12 d. nutarimu Nr. 519 “Dèl Valstybinio strateginio atlieku tvarkymo plano patvirtinimo" patvirtinto Valstybinio strateginio atliekų tvarkymo plano 166.4 punkto (2007 m. spalio 31 d., 2010 m. gruodžio 1 d. redakcijos) atitikties Lietuvos Respublikos Konstitucijai “. Teisésakturegistras. 2014, Nr. 5.

${ }^{11}$ Lietuvos Respublikos aplinkos apsaugos įstatymas. Valstybès žinios. 1992, Nr.5-75.

${ }_{12}$ Lietuvos Respublikos administracinių bylų teisenos įstatymas. Valstybés žinios. 1999, Nr.13-308; Valstybès žinios.2000, Nr.85-2566; Teisès aktų registras 2016, Nr.4. 
public interest or defend the right of the state, municipalities, individual rights and interests protected by law. These interests highlights the protection of nature and the rights to them. It is understood that in defending the public interest and the person's subjective right or legitimate interest the Administrative Proceedings rules are different. That is why court must have to determine all circumstances of the application to protect the public interest in a particular case. To determine whether the applicant applies to the court in defense of subjective rights only or for legitimate interest. When this base is determined the court defines the boundaries of the environmental litigation. However, this does not change the essence of nature protection because in these cases subjects are going to court in order to protect and defend the environment and the right to it. For example, in an administrative case No. A 438-1338/2012 the panel of judges admitted that in applicant's complaint they were concerned about defense of the public and with their private subjective rights (interests). Although the applicant's applied to the court in defense of the particular violation of their subjective rights (interests) related to improper set adjacent parcel boundaries and parcel of the formation (measurement) violation procedures. However, the applicants sought the court assessed as related to the public interest in the field of environmental protection, it means, the applicant's complaint was based on what is important, necessary, useful to society or the part of society. It was the questions about the forest conservation, as well as the public's right to a healthy and clean environment assurance. Although the complaint seeks to ensure that in the forest land assigned to the area will be no construction work and environmental conversion. While analyzing the case law related to the field of environment protection there are no requirements for subjects to go to court on purpose to protect the violated or disputed right or legally protected interest ${ }^{13}$. This right is guaranteed to any concerned entity seeking to preserve and protect the natural values or rights to them.

However, we have to note that the practice in environmental protection field does not always go smoothly, especially when its defense is based on the public interest. The problem is that the Supreme Administrative Court of the Republic of Lithuania state that the public interest in court can be defended only on two conditions: the public interests can be protected only by statutory entities who are going to court and only in cases provided by law. When deciding a violation case of public interest in each case the trial court examining whether a party that complaints to the court, has a legal attorney to protect the public interest. If such right is not granted by law, the court can not satisfy the requirement to protect the public interest. In addition to these two conditions indicated in the case-law there is a one more requirement to apply for a public interest - a real presence of

${ }^{13}$ Lietuvos vyriausiojo administracinio teismo $2012 \mathrm{~m}$. balandžio $2 \mathrm{~d}$. nutartis administracineje byloje Nr. A-858-1193-12.Acvailable at: http://eteismai.lt/byla/181912997890951/A-858-1193-12 (accessed: 21.03 .2017$)$ 
the public interest ${ }^{14}$. Only the court can identify second condition while deciding whether there is a basis to start a trial. All the other entities, regardless of their perceived specific legal relation content imperatively must have to accept it as a fair procedure, since, according to $\mathrm{M}$. Freeman, judge is the one who has an exclusive right to administer justice [Freeman M., 2014: 1617]. If it is determined that the subject does not have the right to go to court, his complaint is rejected according to the Proceeding Law of the Republic of Lithuania, article No 37, part 2, $1^{\text {st }}$ point. And if court decides to start a trial and later finds out that it was done without a reason the case is terminated. The situation is that sometimes the public interest in the protection of nature can be really damaged but entity who complains about it has no attorney. And in the result the natural values and the rights to it are not protected ${ }^{15}$. According to scientists work from University of Chicago we can see a clear conclusion that what is decided in the courts does not necessarily mean that it is right in practice and that in this way the infringement will be reduced [Lawrence S., Tiesma P., 2005: 237]. In practice the situation is emerging in which natural objects or rights to them although illicit vulnerable but they are not protected only because of the legislative formality. After all, the courts have an authority to administer justice and if there is a legal necessity they must have to hand out not only legitimate but also the right decision. The Constitutional Court of the Republic of Lithuania also emphasized that the judiciary power as one of the branches of power must be entitled to execute justice in such way that the expectations of society concerning protection of every person' and the whole society's rights and interests would be satisfied. That is why the judicial authorities for the purpose of a constitutional right must have to hand out only socially valued solutions. And the society is concerned about the correct reception of the final acts ${ }^{16}$. J. Rawls in particular says that the justice can be identified with fairness [Rawls J., 1999: 9]. First of all court shall be honest to itself: the rights are violated and they must be protected regardless of the legislative formalities. While commenting on the fact that while seeking the justice court does not have to be guided only by the law The Constitutional Court of the Republic of Lithuania emphasizes that any court while making a decision in case must follow the law, as well as the main principles of the Constitution: principles of justice, reasonableness, proportionality and fairness ${ }^{17}$.

$142013 \mathrm{~m}$. rugsèjo $23 \mathrm{~d}$. išplèstinès teisèjų kolegijos sprendimas administracinèje byloje Nr. A520211/2013. Lietuvos vyriausiojo administracinio teismo biuletenis. 2013, Nr. 26, p. 271-302.

152013 m. rugpjūčio 19 d. išplèstinès teisèjų kolegijos nutartis administracinèje byloje Nr. A502580/2013. Lietuvos vyriausiojo administracinio teismo biuletenis. 2014, Nr. 26 , p. 207.

${ }^{16}$ Lietuvos Respublikos Konstitucinio Teismo 2006 m. lapkričio 27 d. Nutarimas „Dẻl Lietuvos Respublikos teismų i̇statymo 90 straipsnio 8 dalies $(2002 \mathrm{~m}$. sausio $24 \mathrm{~d}$. redakcija) atitikties Lietuvos Respublikos Konstitucijai." Valstybès žinios. 2006, Nr. 130-4910.

17 Lietuvos Respublikos Konstitucinio Teismo 2008 m. kovo 15 d. Nutarimas „Dèl Lietuvos Respublikos Vyriausybès 2002 m. vasario 6 d. nutarimu Nr. 177 "Dèl Skirtų realizuoti netauriụjų metalų 
Even worse if the «formal" or insufficiently legally based final act of the court has a meaning of the precedent. About such kind of justice the author wrote in the research article "The role of public policy in Taxation: The Case Study of Court Ruling on the Taxation of illegally produced product".

It should be noted that the public interest in the nature preservation is not any interest of a legal person or a group of persons but only the one that reflects and expresses the fundamental values of society that are consolidated, protected and defended by the Constitution of the Republic of Lithuania. Therefore in any case when it comes to a question whether a particular interest can be considered as a public interest it is necessary to establish a fact if alternatively the interest of a person or a group will undermine the values which are protected and defended by the Constitution of the Republic of Lithuania ${ }^{18}$. The Constitutional Court of the Republic of Lithuania emphasized that the state as a whole political organization has a purpose - to protect a human rights and to guarantee the public interest ${ }^{19}$. And the protection of that interest is one of the most important conditions of the existence and development of society ${ }^{20}$. We can see that such public interest at the level of judiciary as well as at the international law level is equivalent to the existence of the nation. And it is understandable because such values as the healthy nature are related to the very existence of the nation. In the following case-law the public interest is not considered to be any legal interest of a single person or group of persons but the one that reflects and expresses the fundamental values of society which are consolidated, protected and defended by the Constitution of the Republic of Lithuania. As mentioned, in practice when it comes to a question whether a particular interest can be considered as a public one it is necessary to

laužo ir atliekų supirkimo licencijavimo taisyklių patvirtinimo" (2004 m. rugpjūčio 31 d. redakcija) patvirtintų Skirtų realizuoti netauriųjų metalų laužo ir atliekų supirkimo licencijavimo taisyklių (2004 m. rugpjūčio 31 d. redakcija) 34 punkto atitikties Lietuvos Respublikos Konstitucijai“. Valstybès žinios. 2008, Nr. 32-1114.

${ }_{18} 2008$ m. liepos 25 d. išplèstinès teisejjų kolegijos nutartis administracinèje byloje Nr. A146335/2008. Lietuvos vyriausiojo administracinio teismo biuletenis. 2008, Nr. 15, p. 184-229.

${ }^{19}$ LR Konstitucinio teismo 2006 m. sausio 16 d. „Nutarimas Dèl Lietuvos Respublikos baudžiamojo proceso kodekso 131 straipsnio 4 dalies (2001 m. rugsèjo 11 d. redakcija) atitikties Lietuvos Respublikos Konstitucijai, dèl Lietuvos Respublikos baudžiamojo proceso kodekso 234 straipsnio 5 dalies (2003 m. balandžio 10 d., $2003 \mathrm{~m}$. rugsèjo $16 \mathrm{~d}$. redakcijos), 244 straipsnio 2 dalies (2003 m. balandžio $10 \mathrm{~d}$., $2003 \mathrm{~m}$. rugsèjo $16 \mathrm{~d}$. redakcijos), 407 straipsnio (2003 m. birželio $19 \mathrm{~d}$. redakcija), 408 straipsnio 1 dalies (2002 m. kovo 14 d. redakcija), 412 straipsnio 2 ir 3 dalių (2002 m. kovo 14 d. redakcija), 413 straipsnio 5 dalies (2002 m. kovo 14 d. redakcija), 414 straipsnio 2 dalies (2002 m. kovo 14 d. redakcija) atitikties Lietuvos Respublikos Konstitucijai ir dèl pareiškejjo - Šiaulių rajono apylinkès teismo prašymų ištirti, ar Lietuvos Respublikos baudžiamojo proceso kodekso 410 straipsnis (2002 m. kovo 14 d. redakcija) neprieštarauja Lietuvos Respublikos Konstitucijai“. Valstybès žinios. 2006, Nr.7-254.

${ }^{20}$ LR Konstitucinio teismo 2005 m. gegužès 13 d. Nutarimas „Dèl Lietuvos Respublikos medžioklès isstatymo 7 straipsnio 2 dalies, 8 straipsnio 1, 9, 10 dalių, 13 straipsnio 2 dalies, 18 straipsnio 7 dalies ir 22 straipsnio 3, 6, 7 dalių atitikties Lietuvos Respublikos Konstitucijai“. Valstybès žinios. 2005, Nr.63-2235. 
establish a fact if alternatively the interest of a person or a group will undermine the values which are protected and defended by the Constitution of the Republic of Lithuania ${ }^{21}$. We have already mentioned that the protection of the environment is a value which must be protected according to the Basic Law of Lithuania. That is why all authorized public entities has a right and a duty to initiate the protection process in the field of nature preservation. But we can state that for a long time Lithuanian legal acts did not contain a concept of nature protection as a public interest. The Constitutional Court of the Republic of Lithuania was trying to fix this matter. In its jurisprudence the Constitutional Court named a values of global significance - certain environmental objects as the public interest. For example, The Constitutional Court stated that the constitutional principle of protection of land shows that the land is treated as a universal value that has a social function to serve to the welfare of the nation. It is a matter of a great importance for the society how land is used because there is a universal need to preserve a productivity of land. It is particularly important that this value would be used in rational and effective way ${ }^{22}$. The forests are also recognized by the Court as a separate and important natural and social value. The Court emphasized that the forest is one of the main natural resources. It is a part of united ecological system, it serves the welfare of society and human, protects the stability of the landscape, fosters the environmental quality. The forest has a special ecological, social and economic significance to environmental public interests and that fact leads to certain limitations and constrains for the owners of forests ${ }^{23}$. Later, while complementing its ruling the Constitutional Court of the Republic of Lithuania stated that the natural environment, fauna and flora, individual objects of nature and particularly valuable areas The Constitution treats as a universal value of national values. And also the Court declared that the natural environment, fauna and flora, individual objects of nature and areas of particular value and protection has to be used and treated rationally the restoration and augmentation must have to be ensured as well as a proper management of populations of inter alia wild animals (their species) ${ }^{24}$.

${ }^{21} 2008 \mathrm{~m}$. liepos 25 d. išplèstinès teisejjų kolegijos nutartis administracineje byloje Nr. A146335/2008. Lietuvos vyriausiojo administracinio teismo biuletenis. 2008, Nr. 15, p. 184-229.

${ }^{22}$ LR Konstitucinio teismo 1996 m. rugsèjo 25 d. Nutarimas "Dèl Lietuvos Respublikos žemès ìstatymo 6 straipsnio pirmosios ir antrosios dalių normų, reguliuojančių vietos savivaldos institucijų teises valstybinès žemès valdymo srityje, ir 24 straipsnio atitikimo Lietuvos Respublikos Konstitucijai“. Valstybès žinios. 1996, Nr.92-2173.

${ }^{23}$ Dèl Lietuvos Respublikos Vyriausybès 1991 m. rugpjūčio 14 d. nutarimo Nr. 329 "Dèl miškams padarytos žalos atlyginimo" 3.4 punkto 3 pastraipos atitikimo Lietuvos Respublikos Konstitucijai“. Valstybès žinios. 1998, Nr.52-1435.

${ }^{24}$ LR Konstitucinio teismo 2005 m. gegužès 13 d. Nutarimas „Dèl Lietuvos Respublikos medžioklès ìstatymo 7 straipsnio 2 dalies, 8 straipsnio 1, 9, 10 dalių, 13 straipsnio 2 dalies, 18 straipsnio 7 dalies ir 22 straipsnio 3, 6, 7 dalių atitikties Lietuvos Respublikos Konstitucijai“. Valstybés žinios. 2005, Nr.63-2235. 
Till that time there were no regulatory imperative concept in the field of natural protection as public interest, it appeared only in 2014 when The Spatial Planning Law and the law of its replacement was adopted. It enshrined the normative content of the public interest in conservation of individual objects ${ }^{25}$. In law it is already established a list of elements that make up the public interest of society for land-use planning process. The article No. 8 of this Law stipulates what constitutes the public interest in planning public areas. For example, it consists of greenery, fertile soil, forests, subterranean and other.

However, we can state the fact that the same violations of the nature protection law decreases every time. Although the decrease is not consistent. For example, in 2013 it was recorded 701 infringements of nature protection rules and in $2014-719$ ones. We can see that infringement increased by $2,6 \%$. However, over 10 years the infringements of nature protection has decreased by more than 3 times [Mareskeviciene I., 2015: 39]. According to the regions the most violations of nature protection set out in Vilnius, where the main economic activity is concentrated. It should be noted that in this region and infringements have a large enduring trend. For example the violations of water protection in Vilnius region reaches 83\% [Mareskeviciene I., 2015: 67].

However as mentioned above in case-law not everyone as a subjects has a right to apply to the court in order to protect the public interest in the field of nature protection. And in court practice it is one of the mandatory conditions. Another condition - it can only be done by law ${ }^{26}$. As already mentioned in addition to the prosecutor the right to apply to the court for protection of public interest in nature conservation has administrative entities, state control officers, other public authorities, institutions, organizations, offices, and in some cases individuals if the court founds the law to allow them to defend a public interes $\mathrm{t}^{27}$. Despite the wide circle of entities with the right to complain to the court for the protection of public interest in the field on nature conservation, the interviews with judges shows that most of the times only prosecutors and public organizations applies to the court regarding this matter. Public organizations (associations) has the right to apply to the courts in order to protect the public interest in the protection of nature and this right is based on already mentioned Administrative Proceeding Law, article No. 5, part 3, point 3 and article No. 56, part 1 and also an article No. 9 of the Aarhus Convention.

However, in accordance with the already mentioned legal acts of the international law, the Constitution of the Republic of Lithuania, the judicial interpretation about the importance of the natural values and by the logic it can be stated

25 Lietuvos Respublikos teritorijų planavimo įstatymas. Valstybés žinios. 2013, Nr.76-3824.

${ }^{26} 2013$ m. rugsėjo 23 d. išplèstinès teisèjų kolegijos sprendimas administracinèje byloje Nr. A520211/2013. Lietuvos vyriausiojo administracinio teismo biuletenis. 2013, Nr. 26, p. 271-302.

27 Lietuvos Respublikos administracinių bylų teisenos įstatymas. Valstybès žinios. 1999, Nr.13-308; Valstybès žinios. 2000, Nr.85-2566; Teisès aktų registras 2016, Nr.0. 
that the environmental protection is not touching only the specific entities, it directly or indirectly affects every person who has not only a personal but also a public interest. That is why anyone, not only a subjects mentioned in law should have a right to initiate the judicial process to protect a nature as a public interest.

\section{Conclusion}

At level of international and national law nature (natural environment) and its protection is considered as one of the most important conditions of the public existence and development in comparison to such fundamental and universally recognized human values as life and health. It obligates the state and its separate institutions to ensure adequate protection of natural values. However, the research shows that a practical policy of the Government while allocating the gross national product funds for nature protection is not sufficient. GPD relative funds should be allocated in the framework of economic activity which is directly dependent on the size of GPD funding for their activities. If there is a disproportionate funding for nature conservation judiciary also gets an important significance concerning the protection and restoration of natural objects.

Although the protection of the environment and the right to it is governed by a number of international and national legislative acts and regulations, environmental relationship at the national level is not enough to adjust both the regulatory framework and the court practice. It is a fact that sometimes nature or the right to it is violated but because of legislative formality it is not protected. Despite the fact that courts are the institutions that have a duty to administer justice and then it is needed courts have to make not only legitimate but also a right decision. But courts are not always fulfilling its constitutional purpose. Moreover judicial obligations in the field of nature conservation are not enough and this field still has issues with realization of law.

Although essentially when entities are going to court to protect their violated or disputed rights or legally protected interest concerning the right to healthy environment there is no additional requirements. But if a person is trying to apply to the court when it comes to the public interest in the field of nature conservation there is an additional conditions. Those are conditions when you are trying to apply for the vases which are not provided by law or when a wrong entity is trying to apply. In such cases, natural objects and rights to it are not protected even if violations exists. In addition, if court decides to deal with the case and in the process mentioned conditions are revealed, the case is terminated. However, in some cases while going to court because of violation of personal environmental rights and if the court itself determines the public interest in that case they become a judicial part of the process as a social significance in environmental field, although only some entities can apply to the court about the public interest. 
As a significant problem in protecting environmental values or right to them is that when entity applies to the court in order to defend the public interest in the field of nature conservation, only the court is competent to determine whether there is a real public interest.

In accordance with the Constitution of the Republic of Lithuania, the courts have a social purpose to administer justice. That is why in cases when because of formal and legal problems there is no enough legal basis to start a trial, assessing the importance of natural values courts should be guided not only by the law but also by the right to start a trial in order to protect these values or rights to them and to create such precedent and a right to the protection of natural values. It should be noted that in some cases if there is no normative act which is needed to regulate a legal relations in the field of nature protection, the legal basis for the protection of nature is provided by the Constitutional Court of the Republic of Lithuania.

Although violations of nature protection have a tendency to decrease but it increases in densely populated areas in Lithuania, especially in Vilnius region where the economic activities are concentrated. It can be stated that both the legislative, the executive and the judiciary powers are not fully justified its purpose in the field of nature protection.

\section{Suggestions}

GDP allocated funds by Government for nature conservation should be calculated in proportion with the funding for other fields, since from funding size depends the scale of economic activity which costs a pollution and this damage must have to be restored.

Since the Constitution of the Republic of Lithuania treats the environment together with the most important human values and obliges every citizen of the Republic to protect it, it turns into an obligation of every entity in the field of nature conservation. To enhance the role of the courts in the environmental protection it is recommended that all entities should have a right to apply to court for nature conservation issues since nature protection directly affects every member of society.

If there is a gap in law about the public interest in nature conservation field defending opportunities in court on the basis of such appeal there should be an elucidation of court.

\section{O-圆 References}

Blanchard O. et al. (2006) Macroeconomics. 4th ed. Upper Saddle River (N.J.): Pearson Publishers, $553 \mathrm{p}$.

Baylis J., Smith S. (2005) The Globalization of World Politics. 3rd ed. Oxford. Oxford University Press, 385 p. 
Bucas J. (2001) Krastotvarkos pagrundai. Kaunas: Technoligija, 188 p. (in Lithuanian)

Danisauskas G. (2015) The role of public policy in taxation: the case study of court ruling on the taxation of illegally produced product. Actual problems of economics, Kiev, no 6 , pp. 51-54.

Davidiuvicius E. (2001) Aplinkos apsaugas vadyba. Vilnius: Litimo Press, 209 p. (in Lithuanian)

De Sombre E. (2006) Global Environmental Institutions. New York — London: Routledge, $402 \mathrm{p}$.

Freeman M. (2014) Introduction to Jurisprudence. London: Sweet and Maxwell, 510 p.

Jablonskienè A. (2014) Gamtos ištekliai ir aplinkos apsauga. Vilnius: Lietuvos statistics leidycla, 198 p. (in Lithuanian)

Jankievicius K., Liuzinas R. (2003) Aplinkos biologinas valdymas. Vilnius: Apyausris, 269 p. (in Lithuanain)

Kramer L. (2012) The EU Environmental Law. 7th ed. London: Sweet and Maxwell, 457 p. Lawrence S., Tiersma P. (2005) Speaking of Crime. The Language of Criminal Justice. Chicago: University Press, 548 p.

Mareškevičienè I. (2015) Aplinkos būklè, tik faktai. Vilnius: Lutute, 254 p. (in Lithuanian) Ozolinikus R. (2008) Aplinkos politika valdymas. Vilnius: MRU Press, 291 p. (in Lithuanian) Rawls J. (1999) A Theory of Justice. Rev. ed. Cambridge (Mass.): Harvard University Press, $414 \mathrm{p}$.

Satkūnas J. (2014) Aplinkos būklè, tik faktai. Kaunas: Kopa Press, 321 p. (in Lithuanian) 